\title{
Kwestia mniejszości ukraińskiej w myśli narodowców w II Rzeczpospolitej
}

\author{
Spoteczeństwo zaś popada $w$ bezmyślność \\ $w$ zakresie najzywotniejszych swoich interesów, \\ $w$ dziedzinach zaś oderwanych od życia okazuje \\ sktonność do ekstaz i orgii duchowych.
}

Roman Dmowski

EWA BAŁUSZYŃSKA - doktorantka Uniwersytetu Papieskiego Jana Pawła II w Krakowie, absolwentka Wydziału Historii i Dziedzictwa Kulturalnego UPJP2. Historyk myśli politycznej II Rzeczpospolitej, a także polskiej emigracji politycznej po roku i945. 
Spory o Rzeczpospolita. Przeglad wybranych dyskusji politycznych $i$ ustrojowych w ostatnim stuleciu, red. P. Gofron, A. Matuła, A. Paderewska, Kraków 2020, s. 24-36.

Toniec I wojny światowej przyniósł nową kartę w dziejach Polski. L Po odzyskaniu niepodległości Rzeczpospolita stanęła przed wielkimi problemami: gospodarczym, politycznymi, a także społecznymi. W ramach nowo utworzonego państwa na terenie Polski znalazło się wiele mniejszości narodowych. W roku 1921 Polskę zamieszkiwało 25694700 osób, Polacy stanowili 69,23\%. Wśród najliczniejszych mniejszości byli Ukraińcy (15, 17\%), Żydzi (7, 97\%), Białorusini $(4,03 \%)^{1}$. Najistotniejszą kwestią dla polskiej polityki była problematyka mniejszości ukraińskiej, ponieważ właśnie ta nacja dążyła do utworzenia własnego samodzielnego bytu państwowego kosztem państwa polskiego. Na negatywne relacje polsko-ukraińskie wpłynął brak spójnej polityki Polski wobec Ukraińców. W latach 30. XX wieku językiem polskim posługiwało się $69 \%$ ogółu społeczeństwa, natomiast ruskim (ukraińskim) blisko $14 \%{ }^{2}$.

Każde stronnictwo polityczne miało swoją wizję, co do rozwiązania tej kwestii. Obóz sanacyjny przyjął krytyczne stanowisko wobec Ukraińców po przewrocie majowym. Z biegiem czasu po zamordowaniu w I93I roku Tadeusza Hołówki³ przez ukraińskich nacjonali-

I H. Zieliński, Historia Polski I9I4-I939, Wrocław I985, s. I 24-I 25.

2 C. Partacz, Polacy i Ukraincy w II Rzeczpospolitej, Kościan I99I, s. I I.

3 Tadeusz Hołówko (I 889-I93 I) - student prawa i filologii polskiej, w latach I 909-I9 I 4 związany ze Związkiem Młodzieży Postępowo-Niepodległościowej oraz z Polską Partią Socjalistyczną - Frakcja Rewolucyjna. Zaangażowany w tworzenie Polskiej Organizacji Wojskowej. Zwolennik potężnego państwa polskiego opartego na fundamentach Unii Lubelskiej. Pragnął 
stów Dmyra Danyłuszna i Wasyla Białasa z OUN polityka wobec Ukraińców się zmieniła: zamykano szkoły ukraińskie na terenie Polski, a także cerkwie, wprowadzono sądy doraźne. W antagonistycznym wobec rządu obozie narodowym zdanie było podzielone. Począwszy od „ojca” narodowców Romana Dmowskiego, który nie popierał i nie wspierał dążeń niepodległościowych państwa ukraińskiego, a skończywszy na „młodych” narodowcach związanych z Janem Mosdorfem, którzy mieli odmienne zdanie, widząc możliwość asymilacji mniejszości, jednakże przeprowadzoną tylko i wyłącznie przymusem. Najdalej idącą koncepcję wysunęli działacze Ruchu Narodowo-Radykalnego „Falanga”, którzy chcieli współpracować z mniejszością ukraińską oraz wspierali dążenia niepodległościowe Ukraińców.

\section{Wizja niepodległej Ukrainy według Romana Dmowskiego}

Kwestia mniejszości ukraińskiej w II Rzeczpospolitej była bardzo burzliwa, każde stronnictwo polityczne przedstawiało własną wizję rozwiązania tego problemu. Jednym z pierwszych wśród narodowców, który poruszył tą kwestię był Roman Dmowski. Polityk poświęcił wiele miejsca temu tematowi w swojej publicystyce. W swoim dziele Kwestia ukraińska z roku 1930 Dmowski przedstawił szczegółowo swoją wizję odnośnie do państwa ukraińskiego. Już na wstępie zaznacza, że

niepodległości Polski, a także Białorusi, Litwy i Ukrainy. Wspólnym wrogiem tych państw była Rosja. Ratunkiem dla Polski miała być współpraca Rzeczpospolitej z Łotwą, Litwą, Estonią, Ukraina, Białorusią i Finlandią. Niechętny wobec Rosji i polityce prorosyjskiej. Inicjator Ukraińskiego Instytuty Naukowego w Warszawie w I930 roku. Zwolennik niepodległej Ukrainy. Uważał, że dla dobrych relacji polsko-ukraińskich należy Ukrainie oddać część Galicji Wschodniej włącznie z Lwowem. Opowiadał się za autonomiom Galicji Wschodniej i Wołynia. Zamordowany z rąk ukraińskich nacjonalistów. 
kwestia Ukrainy jest najważniejszym elementem polskiej polityki zewnętrznej, jak i wewnętrznej4.

Polityk rozpoczyna swój wywód od przedstawienia zmiany znaczenia słowa „Ukraina”. Do końca wieku XIX wyraz ten znaczył ziemie kresowe położone na południowym wschodzie Polski. Jednak z czasem termin ten zmienił znaczenie. W XX wieku wyraz „Ukraina” zaczęto używać do określenia obszaru, gdzie większość ludności mówiła po małorusku (ukraińsku), a także liczba mieszkańców tych terenów sięgała blisko pięćdziesięciu milionów ludzis.

Dmowski dostrzegał, że państwo ukraińskie powstaje w dwóch niezależnych ośrodkach. Pierwszym z nich był teren Ukrainy Naddnieprzańskiej. Był to ruch samoistny, który dążył do utworzenia odrębnej kultury, literatury oraz odrębnego ducha swojego narodu ${ }^{6}$. Przedstawicielem tego ruchu był Taras Szewczenko ${ }^{7}$, który tworzył, jako jeden z pierwszych, w języku ukraińskim. Drugim obszarem, gdzie powstawały zalążki państwa ukraińskiego były tereny Wschodniej Galicji. Dmowski wykazywał, że jest to sztuczny twór, który powstał pod protektoratem Austro-Węgier za namową Niemiec. Polityk przedstawiał, że był to zabieg polityczny mający na celu osłabienie żywiołu polskiego oraz państwa rosyjskiego. Ruch ten nie miał na celu powstania odrębnej kultury ukraińskiej, tylko stworzenie „marionetkowego państwa”.

Z czasem ludność, którą zasiedlano Galicję Wschodnią i południową część państwa rosyjskiego, zaczęto nazywać „Ukraińcami”.

4 R. Dmowski, Kwestia ukrainska, https://konwentnarodowypolski. wordpress. $\mathrm{com} / 2013 /$ I2/o2/ roman-dmowski-kwestia-ukrainska/(8.08.2016).

5 R. Dmowski, Kwestia ukrainska, https://konwentnarodowypolski. wordpress.

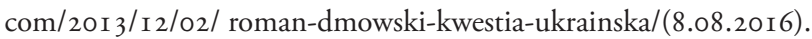

6 R. Dmowski, Kwestia ukrainska, https://konwentnarodowypolski. wordpress.

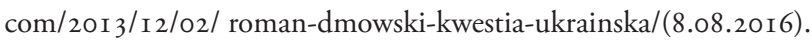

7 Taras Szewczenko - ukraiński poeta narodowy, przedstawiciel literatury rosyjskiej.

8 R. Dmowski, Kwestia ukrainska, https://konwentnarodowypolski. wordpress.

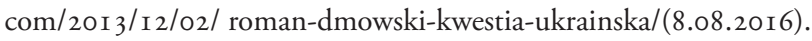


Dmowski wielokrotnie podkreślał, że wspieranie projektu wielkiej Ukrainy przez Niemcy ma na celu osłabienie Rosji i Polski. Państwo niemieckie pod koniec XIX wieku umocniło swoją pozycję w Turcji. Jedyną przeszkodą do realizacji polityki Berlina była pozycja Rosji na Morzu Czarnym oraz jej dostęp do Bałkanów. Polityk przedstawiał, że żywioł ukraiński jest słaby, przy czym jest zróżnicowany etnicznie. Według Dmowskiego do Ukrainy wdarł się czynnik obcy w postaci osadników obcych (niemieckich i żydowskich) głównie w Chersońszyźnie i na Krymie.

Rosja bez Ukrainy jest pozbawiona zboża, żelaza czy też węgla, dlatego też młode państwo ukraińskie stanęłoby w pierwszych dniach swego istnienia w obliczu wojny z wielką Rosją. Dmowski uważał, że Ukraina nie posiadała wykształconej i odpowiedzialnej elity politycznej w strukturach, w której wytworzyłby się czynnik obcy:

Ukraina stała się zbiegowiskiem aferzystów całego świata, którym dziś bardzo ciasno jest we własnych krajach, kapitalistów i poszukiwaczy kapitału, organizatorów przemysłu, techników i kupców, spekulantów i intrygantów, rzezimieszków i organizatorów wszelkiego gatunku prostytucji: Niemcom, Francuzom, Belgom, Włochom, Anglikom i Amerykanom pośpieszyliby z pomocą miejscowi lub pobliscy Rosjanie, Polacy, Ormianie, Grecy, wreszcie najliczniejsi i najważniejsi ze wszystkich Żydzi ${ }^{10}$.

Dmowski uważał, że taka Ukraina stałaby się wrzodem na ciele Europy. Zamiast silnego państwa z własną kulturą, powstałoby międzynarodowe przedsiębiorstwo. Przedstawiał również, że polscy politycy nie powinni wspierać dążeń niepodległościowych Ukrainy. Kwestia ta jest dla polityki zewnętrznej i wewnętrznej bardzo ważna, jednak Polacy nie powinni wspierać Ukrainy, ponieważ:

9 R. Dmowski, Kwestia ukrainska, https://konwentnarodowypolski. wordpress.

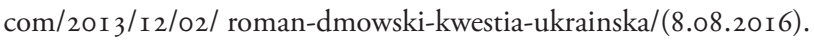

Io R. Dmowski, Kwestia ukrainska, https://konwentnarodowypolski. wordpress.

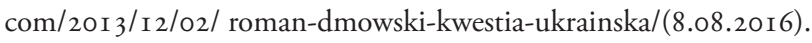


Dla narodu, zwłaszcza dla narodu jak nasz młodego, który musi się jeszcze wychować do swych przeznaczeń, lepiej mieć za sąsiada państwo potężne, choćby nawet bardzo obce i bardzo wrogie, niż międzynarodowy dom publiczny ${ }^{\text {II }}$.

Dmowski twierdził, że te wszystkie czynniki wpływają na to, że niepodległa Ukraina nie ma racji bytu i tym samym nie może liczyć na poparcie ze strony Polaków. Według polityka Polska nie może stanąć po stronie Ukrainy, gdyż tym samym stanie przeciwko Rosji, a na to polska scena polityczna nie mogła sobie pozwolić.

\section{Kwestia ukraińska w myśli Obozu Narodowo- -Radykalnego}

Obóz narodowców był podzielony w kwestii ukraińskiej. Odmienne zdanie i inną wizję, co do kwestii mniejszości ukraińskiej, miał Obóz Narodowo-Radykalny. „Młodzi” narodowcy związani z Janem Mosdorfem uważali, że Kresy to część Polski, która jest nieoddzielną częścią Polski ${ }^{12}$. Mosdorf napisał, że Ukraińcy nie są mniejszością narodową,

gdyż z racji odrębnych narzeczy nie poczuwa się nawet do mniejszości polskiej ani żadnej w ogóle. Z tego powodu też trudno tych mieszkańców traktować, wprost jako Polaków albo jeszcze trudniej, jako jakieś mniejszości narodowe ${ }^{13}$.

Mosdorf ludność autochtoniczną Kresów nie traktował jako mniejszości narodowej. Dla „młodych” narodowców jedyną drogą asymilacji ludności ukraińskiej był proces przymusu, uważali bowiem, że

I I R. Dmowski, Kwestia ukrainska, https://konwentnarodowypolski. wordpress.

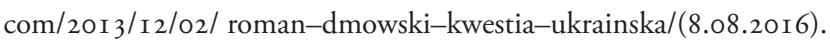

I 2 . Rudnicki, Obóz Narodowo Radykalny. Geneza dziatalności, Warszawa I985, s. I09.

I 3 J. Mosdorf, Akademik i polityka, Warszawa I929, s. Iо. 
Ukraińcom należy narzucić wszelkie prawa polskie, język polski oraz kulturę polską.

Tadeusz Gluziński ${ }^{14} \mathrm{w}$ swym artykule Sprawa ukrainska przedstawił, że Ukraina to coś odrębnego, „ludność Ukrainy naddnieprzańskiej i ludność ruska Wschodniej Małopolski - to z dziejów, religii i cywilizacji coś istotnie odrębnego"ss. Przeciwnie niż Roman Dmowski Gluziński uważał, że przy pomocy Niemiec Ukraina zniszczy Rosję, a Polsce pomoże dojść nad Dniepr: „Ukraina przy pomocy Niemiec i Polski stanie się tym taranem, który rozbije Rosję i tym pomostem, po którym Polska dojdzie nad Dniepr" ${ }^{\text {"I6 }}$. Była to daleko idąca wizja wśród narodowców, gdyż większość z nich była zwrócona w stronę rosyjską, a przeciwna polityce niemieckiej. Gluziński wykazywał, że konflikt Małopolski Wschodniej wziął się z aspiracji zdobywczej Ukrainy Zachodniej oraz wyraźnymi granicami religijnymi, historycznymi, gospodarczymi, a nawet politycznymi, które panowały między nimi. Polityk również wykazywał, że kwestia ruska w Małopolsce Wschodniej to problem polskiej polityki wewnętrznej i nie należy tej kwestii łączyć ze sprawą ukraińską ${ }^{17}$. Natomiast kwestia Ukrainy Naddnieprzańskiej jest problemem polskiej polityki zagranicznej. Nasz stosunek do niej powinien być zależny od naszych relacji z Niemcami i Rosją.

Grudziński przedstawiał, że polska polityka wobec Ukrainy nie powinna być prowadzona par force, uważał bowiem, iż taka polityka jest nieskuteczna, a odrębnej etnicznie, religijnie i kulturowo ludności nie da się siłą spolonizować. Jednak, aby polepszyć relacje polsko-

I4 Tadeusz Gluziński - polski działacz polityczny, publicysta i ideolog ruchu narodowego, członek Stronnictwa Narodowego i Obozu Narodowo-Radykalnego w okresie II Rzeczpospolitej oraz Grupy „Szańca” podczas drugiej wojny światowej.

I 5 T. Gruziński, Sprawa ukraińska, w: Życie i śmierć dla narodu. Antologia myśli narodowo-radykalnej z lat 30. XX wieku, A. Meller, P. Tomaszewski, Warszawa 20 I I, s. 359.

I6 T. Gruziński, Sprawa ukrainska, dz. cyt., s. 360.

I7 T. Gruziński, Sprawa ukraińska, dz. cyt., s. 360. 
-ukraińskie należy wprowadzić świadomą politykę i dokonać zbliżenia cywilizacyjnego i duchowego ludności ukraińskiej i polskiej ${ }^{18}$. Polityk wykazywał, że autonomia gospodarcza ludności ruskiej przy poparciu Ukraińców z Małopolski ma na celu odgrodzenie ludności polskiej (mieszkającej na tym terenie) od państwa polskiego.

Gluziński prezentował pogląd, że Polacy i ludność ruska są od siebie odseparowani, ponieważ nie znają języka. Polityk przedstawia, że język ruski (ukraiński) jest dla Polaków wstrętny i ludność polska go lekceważy. Polscy urzędnicy w kontaktach z Ukraińcami posługują się językiem polskim, wskutek czego dochodzi do nieporozumień. W ten sposób jedna i druga strona separuje się od siebie. Polityk uzasadniał, że jedyną drogą, by rozwiązać tą sytuację, byłaby nauka języka ukraińskiego przez Polaków ${ }^{19}$.

W artykule Jak trwale rozwiąać zagadnienie mniejszości stowiańskiej autor przedstawiał, że ludności kresowej brakuje narodowości nie umiała się określić. Do głównych różnic dochodzi na tle religii: katolickiej, protestanckiej oraz unickiej ${ }^{20}$. Uświadamia również, że dotychczasowa polityka jest bezplanowa, chwiejna i niezdecydowana. Autor ukazuje , że obecna polityka państwa Polskiego prowadzi do oddzielenia się Ukraińców. W artykule przedstawiono dwie zasady prowadzenia polityki wobec kresowian. Pierwszą z nich miała być zasada równouprawnienia. Należy przyjmować ludność ukraińską do politycznych organizacji narodu w celu uwolnienia ich spod kontroli żydowskiej ${ }^{21}$. Niezbędne jest także wychowanie młodych kresowian w jedności z narodem polskim. Drugą zasadą miało być wciągnięcie mas kresowych w życie polityczne narodu. Zadaniem polskich polityków ma być przedstawienie atrakcyjności polskiej kultury w taki

I 8 T. Gruziński, Sprawa ukraińska, dz. cyt., s. 362.

I9 T. Gruziński, Sprawa ukrainska, dz. cyt., s. 364.

20 H. L., Jak trwale rozwiązá zagadnienie mniejszości stowiańskiej, w: Życie iśmierć dla narodu. Antologia myśli narodowo-radykalnej z lat 3o. XX wieku,

A. Meller, P. Tomaszewski, Warszawa 20 I I, s. 365.

2 I H. L., Jak trwale rozwiązać zagadnienie mniejszości stowiańskiej, dz. cyt., s. 366. 
sposób, by do niej zachęcić. Autor zaznaczył, że na tych ziemiach mieszkało wielu Polaków i należało zadbać o to, aby nie dochodziło do podziału między ludnością polską i ukraińską ${ }^{22}$.

Powodzenie ma zapewnić prowadzenie jednolitej i konsekwentnej polityki. Połączenie dwóch zasad wpłynie na jedność i pomyślny proces asymilacji ludności Kresów.

\section{Wizja wolnej Ukrainy w perspektywie Ruchu Narodowo-Radykalnego}

Jeden z najbardziej skrajnych odłamów polskich narodowców, jakim był Ruch Narodowo-Radykalny „Falanga” również zaprezentował swoją wizję w sprawie Ukrainy. Bolesław Piasecki przedstawiał, że obywatelem państwa polskiego może być tylko i wyłącznie Polak. Polityk twierdził, że Ukraińcy mogą wchodzić w skład narodu polskiego, jako integralna część o silnym znaczeniu regionalnym²3.

„Falanga” poświęciła osobny punkt w swym programie, opisując swoją wizję mniejszości na terenach Rzeczpospolitej: „Mniejszości słowiańskie zdobędziemy dla Polski przez asymilację mas i zwalczanie wrogich jednostek" ${ }^{24}$. Ruch Narodowo-Radykalny chciał dokonać procesu asymilacji nie drogą siłową, nie przez naiwne schlebiania czy też mechaniczne od górne nakazy, ale za pomocą pokojowych i dobrowolnych rozwiązań. Należy zaznaczyć, że „Falanga” pod pojęciem mniejszości słowiańskich miała na myśli Ukraińców i Białorusinów, przy czym tylko Ukraińców uważali za samodzielny naród ${ }^{25}$. Narodowi radykałowie przedstawiali, że budowanie gospodarki i kultury Kresów należy prowa-

\footnotetext{
22 H. L., Jak trwale rozwiązać zagadnienie mniejszości stowiańskiej, dz. cyt., s. 366 .

23 S. Rudnicki, Obóz Narodowo Radykalny. Geneza dziatalności, dz. cyt., s. I8o.

24 B. Piasecki, Zasady programu narodowo-radykalnego, Warszawa I937, s. I I.

25 R. Broniarek, Ruch narodowo-radykalny „Falanga” w świetle pism programowych, Krzeszowice 20 I I, s. I 2 I.
} 
dzić przy pomocy Powszechnej Organizacji Wychowawczej, ponieważ takie działania doprowadzą do zbliżenia nacji. Bepiści ${ }^{26}$ wykazywali również, że Ukraińcy mają prawo do utworzenia własnego państwa na terenach macierzystych, przy jednoczesnej nienaruszalności granic państwa Polskiego. Ruch Narodowo-Radykalny wyraźnie zaznaczył w swoim programie, że wszelka działalność, która będzie miała na celu oderwanie ziem polskich, będzie uniemożliwiona i powstrzymana ${ }^{27}$. Radykałowie uważali naród ukraiński za świadomy, jednakże ze względu na krwawe historyczne połączenie Polaków i Ukraińców należy podchodzić do nich z dozą niepewności i prowadzić ostrożny proces asymilacji.

Działania asymilacyjne miały polegać na wprowadzeniu kalendarza gregoriańskiego, alfabetu łacińskiego, wprowadzenia celibatu wśród księży w Kościele greckokatolickim oraz wykształcenie wśród ukraińskiej ludności mającej polską świadomość narodową. Proces ten mógł przebiec pomyślnie pod czterema warunkami:

I. przedstawienie atrakcyjności polskiej idei narodowej - w celu zachęcenia, a nie zniechęcenia;

2. prowadzenie konsekwentnej ,żelaznej linii politycznej” - w celu zabezpieczenia polskiego interesu;

3. podniesienie gospodarki terenów wschodnich - w celu podniesienia gospodarki Polski;

4. równe traktowanie Polaków i Ukraińców przez społeczeństwo i władzę - w celu zażegnania konfliktów między nimi ${ }^{28}$.

Tylko i wyłącznie prowadzenie takiej polityki, zdaniem członków „Falangi”, może przynieść pozytywne rezultaty. Należy podkreślić również, że antyżydowski program Ruchu Narodowo-Radykalnego był bardzo atrakcyjny dla ukraińskich nacjonalistów. Zarówno „Falanga”, jak

26 Bepiści - nazwa działaczy Ruchu Narodowo-Radykalnego „Falanga”, która się wzięła od inicjałów przywódcy - Bolesław Piasecki.

27 R. Broniarek, Ruch narodowo-radykalny „Falanga” w świetle pism programowych, dz. cyt., s. I23.

28 R. Broniarek, Ruch narodowo-radykalny „Falanga” w świetle pism programowych, dz. cyt., s. I 24. 
i ukraińscy nacjonaliści nie wykluczali wzajemnej współpracy. Bepiści uzasadniali, że żywioł ukraiński nie wykazuje żadnych zdolności panstwowych, jednak jest świeży, prężny w działalności politycznej oraz odmienny etnicznie, co należy wykorzystać i nawiązać z nimi współpracę ${ }^{29}$.

\section{Zakończenie}

Sprawa ukraińska w okresie międzywojennym była kwestią burzliwą i niezwykle trudną do rozwiązania. Stanowiska, co do jej rozwiązania były bardzo podzielone. W samym obozie narodowym powstało kilka koncepcji, począwszy od samego Romana Dmowskiego, który krytycznie podchodził do wizji niepodległej Ukrainy. Polityk wykazywał, iż wolne państwo ukraińskie niesie ze sobą szereg negatywnych skutków dla Polski, Rosji i samej Europy. Dostrzegał również, że w sprawę ukraińską zamieszane są Niemcy, które chciały osłabić politycznie i ekonomicznie Rosję oraz Polskę. „Młodzi” narodowcy związani z Janem Mosdorfem i Obozem Narodowo-Radykalnym widzieli możliwość asymilacji ludności ukraińskiej, jednakże proces ten mógł być przeprowadzony tylko i wyłącznie drogą przymusu. Uważali bowiem, że mniejszość ukraińska nie poczuwa się do bycia mniejszością na ziemiach polskich i dlatego należy ją zmusić do nauki języka polskiego. Tadeusz Gluziński uważał, że Ukraina może być tym czynnikiem, który pomoże Polsce dotrzeć nad Dniepr. Wykazywał, że żywioł ukraiński należy nakierować tak, by wspierał sprawę polską. Najbardziej posunięte postulaty wnioskowali działacze Ruchu Narodowo-Radykalnego „Falanga”. Postulowali oni, aby zasymilować masy ukraińskie dla sprawy polskiej. Zaznaczali, że Ukraina ma prawo do niepodległego państwa, jednakże nie może naruszyć ziem terytorialnych Polski. Uważali również, iż żywioł ukraiński jest niezwykle

29 R. Broniarek, Ruch narodowo-radykalny "Falanga” $w$ świetle pism programowych, dz. cyt., s. I25. 
prężny i świeży politycznie i dlatego warto z nimi współpracować Radykałowie dążyli do asymilacji mniejszości przez szerzenie języka polskiego, kultury oraz wiary katolickiej.

Żadna z tych koncepcji nie została zrealizowana. Niestety, można śmiało stwierdzić, że kwestia mniejszości ukraińskiej na kresach nie została należycie rozwiązana. W czasie II wojny światowej i tuż po niej miało to negatywne skutki m.in. w licznych grabieżach i mordach na ludności polskiej czy też w postaci ludobójstwa przeprowadzonego na Polakach przez Ukraińską Powstańczą Armię. Częsta współpraca Ukraińców (także z Niemcami), Białorusinów czy Litwinów z Sowietami doprowadziła do licznych zsyłek na Syberię polskiej inteligencji, oficerów Wojska Polskiego oraz urzędników państwowych.

\section{Streszczenie}

KWESTIA MNIEJSZOŚCI UKRAIŃSKIE W MYŚLI NARODOWCÓW W II RZECZPOSPOLITEJ

Artykuł dotyczy podejścia różnych organizacji narodowych do zagadnienia ukraińskiego. Wraz z odzyskaniem niepodległości mniejszość ukraińska stanowiła ok. 15\% mieszkańców Polski. Własną wizję tworzenia państwa ukraińskiego i procesu asymilacji stworzył obóz narodowy. W artykule przedstawiono wizję niepodległego państwa ukraińskiego według Romana Dmowskiego, a także koncepcję wolnej Ukrainy w ujęciu Ruchu Narodowo-Radykalenego.

\section{Summary}

ISSUE OF THE MINORITY UKRAINIAN IN THE THOUGHT OF NATIONALISTS IN THE SECOND POLISH REPUBLIC

Article is regarding the approach of nationalist various organisations towards the issue of the Ukrainian. Along with regaining indepen- 
dence the Ukrainian minority determined about $15 \%$ of inhabitants of Poland. A national camp created the own vision of creating the state of the Ukrainian and the process of the assimilation. In the article a vision of the independent state of the Ukrainian was presented according to Roman Dmowski, as well as the concept of free Ukraine in taking the National-adical Movement away.

\section{Bibliografia}

Broniarek R., Ruch narodowo-radykalny „Falanga” w świetle pism programowych, Krzeszowice $201 \mathrm{I}$.

Dmowski R., Kwestia ukrainska, https://konwentnarodowypolski. wordpress.com/2013/12/O2/roman-dmowski-kwestia-ukrainska/ (8.08.2016).

Gruziński T., Sprawa ukrainska, Warszawa 1937.

H. L., Jak trwale rozwiazać zagadnienie „mniejszości stowiańskich”, „Jutro. Pismo dla wszystkich” 1937 nr 22, w: Życie i śmierć dla narodu. Antologia myśli narodowo-radykalnej z lat 3o. XX wieku, oprac.

A. Meller, P. Tomaszewski, Warszawa 20II, s. 357-359.

Mosdorf J., Akademik i polityka, Warszawa 1929.

Partacz C., Polacy i Ukraincy w II Rzeczpospolitej, Kościan I99I.

Piasecki B., Zasady programu narodowo-radykalnego, Warszawa 1937.

Rudnicki S., Obóz Narodowo Radykalny. Geneza i dziatalność, Warszawa I985.

Zieliński H., Historia Polski I9I4-I939, Wrocław 1985. 
A. Uniwersytet Papieski

过, Jana Pawła II

(b w Krakowie 